\title{
Apoptosis Review Series
}

\section{The activation of Akt/PKB signaling pathway and cell survival}

\author{
Gang Song a, Gaoliang Ouyang a, Shideng Bao a,b * \\ a The Key Laboratory of the Ministry of Education for Cell Biology and Tumor Cell Engineering, \\ School of Life Sciences, Xiamen University, \\ Xiamen, China \\ b Department of Pharmacology and Cancer Biology, Duke University Medical Center, \\ Durham, North Carolina, USA
}

- Introduction

- Structural features of Akt/PKB protein kinases

- Regulation of Akt/PKB activity

-Phosphoinositide 3-kinase (PI3-Kinase)

dependent activation of Akt/PKB

- Membrane translocation

- Phosphorylation of Akt/PKB

- Phosphorylation of Thr308

- Phosphorylation of Ser473

- Phosphorylation of tyrosine residues

-Phosphoinositide 3-kinase (PI3-Kinase)

independent activation of $\mathrm{Akt} / \mathrm{PKB}$

-Proteins bind and regulate Akt/PKB
- Regulation of cell survival by Akt/PKB

-Direct regulation of cell survival

- BAD

- Caspase-9

- SAPK

-Transcriptional control of cell survival

- FoxO Forkhead

$-\mathrm{NF}-\mathrm{kB}$

- Mdm2

- CREB

- YAP

-Metabolic regulation of cell survival

- Conclusions

\begin{abstract}
$\mathrm{Akt} / \mathrm{PKB}$ is a serine/threonine protein kinase that functions as a critical regulator of cell survival and proliferation. Akt/PKB family comprises three highly homologous members known as PKB $\alpha / A k t 1, P K B \beta / A k t 2$ and PKB $\gamma / A k t 3$ in mammalian cells. Similar to many other protein kinases, Akt/PKB contains a conserved domain structure including a specific $\mathrm{PH}$ domain, a central kinase domain and a carboxyl-terminal regulatory domain that mediates the interaction between signaling molecules. Akt/PKB plays important roles in the signaling pathways in response to growth factors and other extracellular stimuli to regulate several cellular functions including nutrient metabolism, cell growth, apoptosis and survival. This review surveys recent developments in understanding the molecular mechanisms of Akt/PKB activation and its roles in cell survival in normal and cancer cells.

Keywords: Akt/PKB - protein phosphorylation - cell survival • apoptosis

* Correspondence to: Shideng BAO,

The Key Laboratory of the Ministry of Education for Cell

Biology and Tumor Cell Engineering, School of Life Sciences,

Xiamen University, Xiamen 361005, China.

Tel: +86-592-2186091

Fax: +86-592-2186091

E-mail: sdbao26@yahoo.com
\end{abstract}




\section{Introduction}

Akt/PKB protein kinase, a serine/threonine kinase, belongs to the cAMP-dependent protein kinase $\mathrm{A} /$ protein kinase $\mathrm{G} /$ protein kinase $\mathrm{C}$ (AGC) super family of protein kinases that share structural homology within their catalytic domain and have the similar mechanism of activation. Deregulations of some of these kinases are frequently associated with human diseases including cancer and diabetes $[1,2]$. Akt/PKB was initially identified by three independent groups, based on its homology to protein kinase A (PKA) [3] and C (PKC) [4] or as the cellular homolog to the retroviral oncogene viral akt (v-Akt) [5]. In mammals, three Akt/PKB genes have been identified, termed PKB $\alpha /$ Akt1 [6], PKB $\beta / A k t 2$ [7] and PKB $\gamma /$ Akt3 [8], located at chromosomes $14 \mathrm{q} 32,19 \mathrm{q} 13$, and 1q44, respectively.

Over the past decade, Akt/PKB has emerged as a central player in the signal transduction pathways activated in response to growth factors or insulin and is thought to contribute to several cellular functions including nutrient metabolism, cell growth, transcriptional regulation and cell survival [9]. In this review, we discuss the molecular mechanisms of Akt/PKB activation and its important functions in regulating cell survival particularly.

\section{Structural features of Akt/PKB protein kinases}

All three Akt/PKB isoforms consist of a conserved domain structure: an amino terminal pleckstrin homology $(\mathrm{PH})$ domain, a central kinase domain and a carboxyl-terminal regulatory domain that contains the hydrophobic motif, a characteristic of AGC kinases. The major structural features of the $\mathrm{Akt} / \mathrm{PKB}$ proteins are illustrated in Fig. 1.

The N-terminal PH domain consisting of approximately 100 amino acids was originally found in pleckstrin, the major phosphorylation substrate for PKC in platelets [10]. Recent detailed structural examination revealed that the $\mathrm{PH}$ domain of Akt/PKB shares similarity to those found in other signaling molecules that bind 3-phosphoinositides $[11,12]$. The PH domain interacts with membrane lipid products such as phosphatidylinositol $(3,4,5)$ trisphosphate (PIP3) produced by phosphatidyli- nositol 3-kinase (PI3-kinase). Biochemical analysis demonstrated that the $\mathrm{PH}$ domain of Akt/PKB binds to both PIP3 and PIP2 with similar affinity $[13,14]$. Recently, the crystal structure of the $\mathrm{PH}$ domain of Akt/PKB has been solved [15].

The kinase catalytic domain of Akt/PKB, located in the central region of the molecule, shares a high degree of similarity with other AGC kinases such as PKA, PKC, p70S6K and p90RSK [16]. Another feature in this region is a conserved threonine residue (T308 in $\mathrm{PKBa} / \mathrm{Akt1}$ ) whose phosphorylation can partially activate Akt/PKB [17].

Following the kinase domain there is a carboxyl terminal extension of around 40 amino acids. This region possesses the $\mathrm{F}-\mathrm{X}-\mathrm{X}-\mathrm{F} / \mathrm{Y}-\mathrm{S} / \mathrm{T}-\mathrm{Y} / \mathrm{F}$ hydrophobic motif (where $\mathrm{X}$ is any amino acid) that is characteristic of the AGC kinase family [16]. For all AGC family kinases, phosphorylation of the Serine or Threonine residue in this hydrophobic motif is necessary for full activation of the kinase. In mammalian Akt/PKB isoforms, this motif is identical (FPQFSY), and is thought to be critically important, because a deletion mutant of this motif completely abolishes enzymatic activity [18]. But the rat PKB $\gamma / \mathrm{Akt} 3$ and the human PKBa/Akt1 splice variant do not possess this motif, suggesting that these variant kinases are activated by mechanisms independent of phosphorylation of the Serine/Threonine residues in the hydrophobic motif $[19,20]$.

\section{Regulation of Akt/PKB activity}

All Akt/PKB isoforms except the $\mathrm{PKBg} / \mathrm{Akt} 3$ splice variant contain two regulatory phosphorylation sites, Thr308 in the activation loop within the kinase domain and Ser473 in the C-terminal regulatory domain (Fig. 2). Activation of Akt1/PKBa by growth factors involves a PI3-Kinase- and $\mathrm{PH}$ domaindependent membrane translocation step, followed by phosphorylation of these two key regulatory sites. Phosphorylation of $\mathrm{Thr} 308$ partially activates $\mathrm{Akt} / \mathrm{PKB}$, while phosphorylation of both sites is required for full activation. Significantly, phosphorylation of Ser473 alone has little effect on Akt/PKB activity [17]. In addition, a number of novel Akt/PKB binding proteins have been identified and these proteins could regulate the activity of Akt/PKB (Table 1). 
$P K B \alpha / A c t 1$

$P K B \beta / A c t 2$

PKB $\gamma / A$ ct3

PKB $\gamma 1$
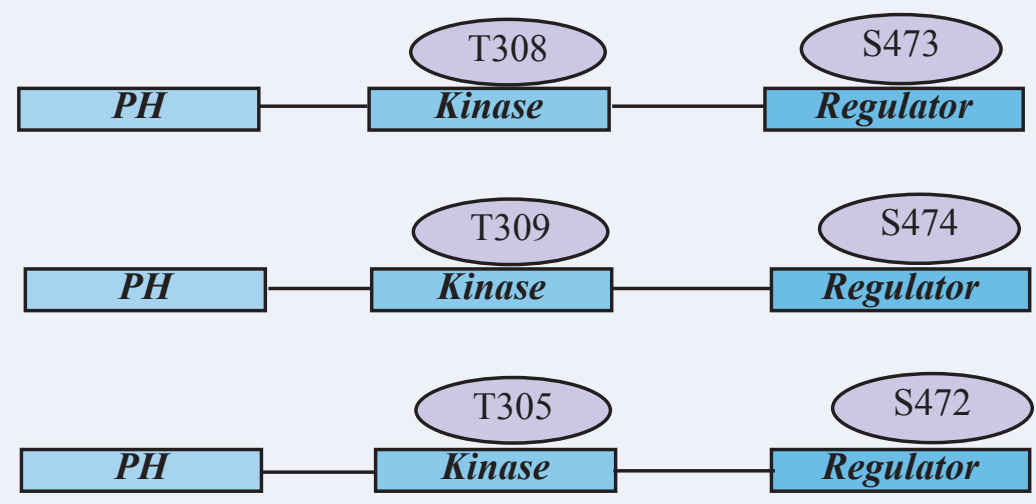

T305

Fig. 1 Domain structure of human Akt/PKB isoforms and the PKB $\gamma / \mathrm{Akt} 3$ splice variant (PKB $\gamma 1)$.

\section{Phosphoinositide 3-kinase (PI3-Kinase) -dependent activation of Akt/PKB}

\section{Membrane translocation}

Akt/PKB, as the downstream effectors of PI3Kinase, is activated by Class 1A and Class 1B PI3Kinase, and Class 1A and Class 1B PI3-Kinase are activated by tyrosine kinase and G-protein-coupled receptors, respectively [21]. Following its recruitment to these receptors in the plasma membrane, PI3-Kinase is activated and PIP2 on the 3-OH group generates the second messenger PIP3. PIP3 levels are tightly regulated by the action of phosphatases such as PTEN, which removes phosphate from the 3-

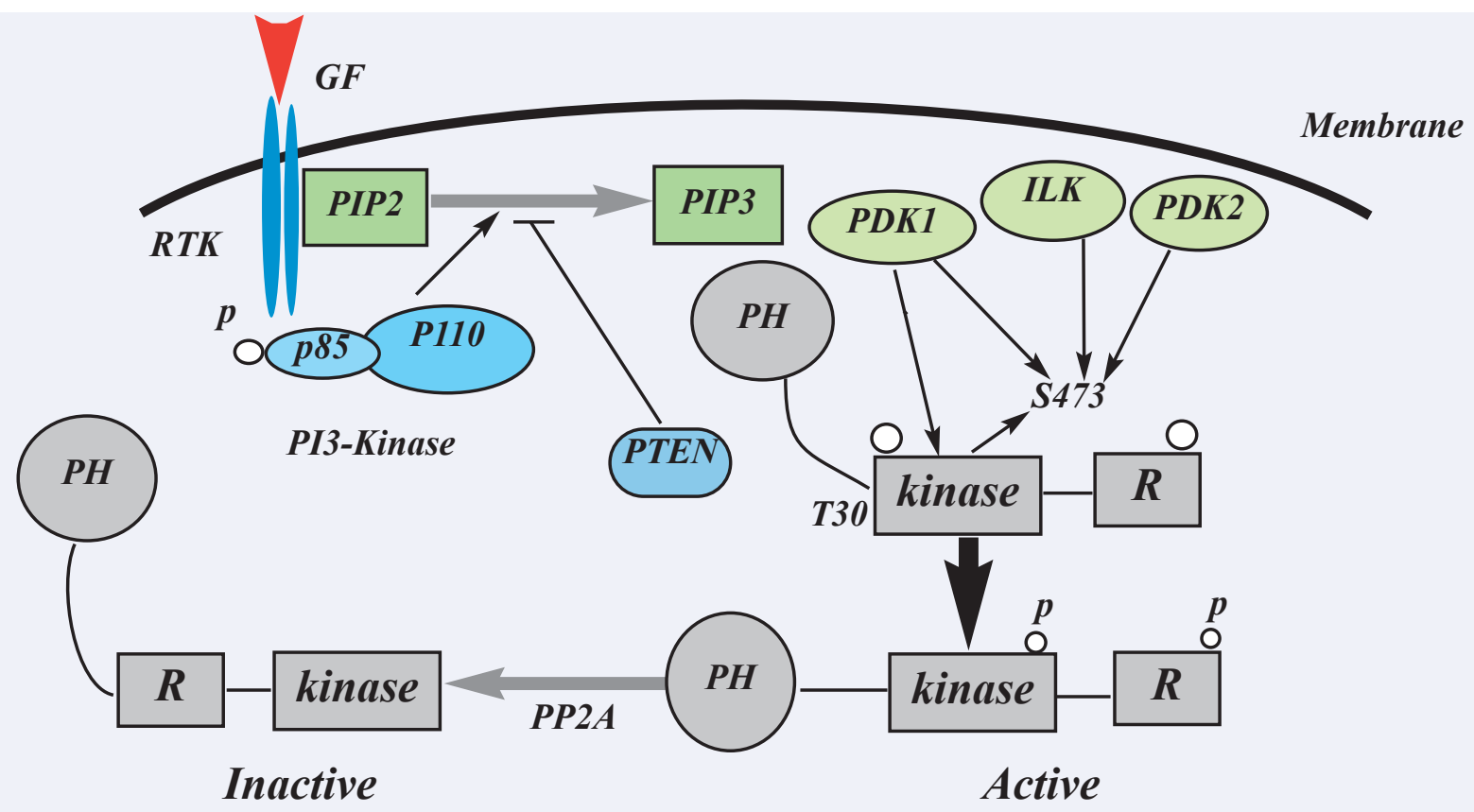

Fig. 2 Mechanism of Akt/PKB activation. GF: growth factor, p: phosphorylation, RTK: receptor tyrosine kinase, R.: regulator. 
$\mathrm{OH}$ position [22]. The $\mathrm{PH}$ domains containing 100 amino acid modules found in many signaling proteins can mediate protein-lipid interactions [23]. In the case of $\mathrm{Akt} / \mathrm{PKB}$, the $\mathrm{PH}$ domain is required for its recruitment to the plasma membrane through high-affinity binding to PIP3 produced by activated PI3-Kinase [24]. PIP3 does not activate Akt/PKB directly, but instead appears to recruit $\mathrm{Akt} / \mathrm{PKB}$ to the plasma membrane and to alter its conformation to allow subsequent phosphorylation by the phosphoinositide- dependent kinase-1 (PDK1).

\section{Phosphorylation of Akt/PKB}

Akt/PKB is activated by site-specific phosphorylation. For PKB $\alpha / A k t 1$, a main site of phosphorylation is within the activation T-loop at Thr308. There is convincing evidence that Thr308 is phosphorylated by the PDK1 [25]. The other phosphorylation site for $\mathrm{PKB} / \mathrm{Akt1}$ is Ser473, the mechanism of its phosphorylation is not completely understood. But there is evidence suggesting that the site can be autophosphorylated [26] or phosphorylated by distinct serine kinases including the integrin-linked kinase (ILK) [27]. Furthermore, several recent reports have investigated the possible role of tyrosine phosphorylation in Akt/PKB regulation [28,29].

\section{Phosphorylation of Thr308}

PDK1 is a $63-\mathrm{kDa}$ serine/threonine kinase containing a C-terminal $\mathrm{PH}$ domain that binds with high affinity to 3-phosphoinositides. The primary structure of this kinase is similar to other AGC kinase family members, and it has a $\mathrm{PH}$ domain at its carboxyl-terminal [30]. When full-length of Akt/PKB is used as a substrate for PDK1, PIP3 is required for maximal activity. In contrast, when a $\mathrm{PH}$ domain deletion mutant of $\mathrm{Akt} / \mathrm{PKB}$, or a peptide substrate corresponding to the activation loop of $\mathrm{Akt} / \mathrm{PKB}$ that contains a PDK1 phosphorylation site is used, the PIP3 dependency for PDK1 activity was completely abolished [31]. This indicates that the enzymatic activity of PDK1 is not a target of phosphoinositide and that the $\mathrm{PH}$ domain of Akt/PKB might act as an inhibitor for Thr308 phosphorylation by masking this residue from PDK1. The mechanism for phosphorylation of Akt/PKB on Thr308 seems to be different from other AGC kinases such as SGK, p70S6K and p90RSK [32,33]. For Akt/PKB, co-localization with PDK1 is necessary for phosphorylation on Thr308 [18,34].

\section{Phosphorylation of Ser473}

Although phosphorylation at T308 partially activates Akt/PKB [17], full activation of Akt/PKB requires phosphorylation on a second site (Such as $\mathrm{S} 473$ in $\mathrm{PKB} \alpha / \mathrm{Akt} 1)$ located in the regulatory tail. The mechanism mediating Ser473 phosphorylation remains controversial. Since Ser473 phosphorylation is dependent on PI3-kinase, as well as Thr308, PDK1 was assumed to be the kinase for Ser473 phosphorylation [35]. However, PDK1 knockout ES cells disproved this prediction. In these cells, Ser473 was phosphorylated similar to wild-type cells, whereas Thr308 phosphorylation was completely abolished [36]. However, the phosphorylation level of Akt/PKB on Ser473 increases by overexpressing PDK1 in transfected cells [37]. This finding indicates that PDK1 may contribute indirectly in the process of Ser473 phosphorylation. Several groups reported that $\mathrm{Akt} / \mathrm{PKB}$ itself could autophosphorylate Ser473 under certain conditions $[38,39]$. Other findings suggest that $\mathrm{S} 473$ is modified by a distinct kinase such as PDK-2 [40].

The integrin-linked kinase (ILK) was shown to phosphorylate Ser473 too [41]. But a subsequent report suggested that ILK acts only as a facilitator and does not phosphorylate Akt/PKB directly [42]. More recent studies showed that ILK could phosphorylate Akt/PKB on Ser473 and that the kinase activity of ILK was essential for Ser473 phosphorylation in cells. A novel ILK-specific inhibitor also blocked Ser473 phosphorylation of Akt/PKB [43]. These studies strongly suggest that ILK plays some roles in the activation process, but whether it phosphorylates $\mathrm{Akt} / \mathrm{PKB}$ directly is controversial.

\section{Phosphorylation of tyrosine residues}

Several recent reports have described the possible role of tyrosine phosphorylation in Akt/PKB regulation $[28,29]$. One report indicated that two tyrosine residues located within the catalytic domain of Akt/PKB, Tyr315 and Tyr326, are phosphorylated following receptor activation and are required for activity, since mutation to phenylalanine abolished kinase activity [44]. Another 
report identified Tyr474, based on phosphopeptide mapping, as a possible site of phosphorylation in response to insulin and pervanadate, and indicated phosphorylation at Tyr474 is required for full activation of Akt/PKB [28]. These observations indicated a novel regulatory mechanism for $\mathrm{Akt} / \mathrm{PKB}$. This tyrosine is conserved widely in the AGC family, suggesting that a possible mechanism of regulation could be a general feature. But further experiments are needed to evaluate the role of Tyr474 in Akt/PKB regulation.

\section{Phosphoinositide 3-kinase (PI3-Kinase)- independent activation of $\mathrm{Akt} / \mathrm{PKB}$}

Several reports have suggested that Akt/PKB could be activated in a PI3-kinase-independent manner. cAMP-elevating agents such as forskolin, chlorophenylthio-cAMP, prostaglandin-E1, and 8-bromo-cAMP were shown to activate Akt/PKB through PKA $[45,46]$. The $\mathrm{PH}$ domain of $\mathrm{PKBa} / \mathrm{Akt1}$ is not required for this activation and phosphorylation of Ser473 is not necessary for the PKA induced activation, while the phosphorylation of Thr308 is required. However, the mechanism by which PKA activates Akt/PKB is not fully clear [46]. PKA does not activate PI3kinase and the cAMP-mediated activation of $\mathrm{Akt} / \mathrm{PKB}$ is wortmannin resistant, so it was concluded that the activation is PI3-kinase independent [46].

It was also shown that Akt/PKB can be activated by $\mathrm{Ca} 2^{+} /$calmodulin-dependent kinase directly in vitro [47]. Other reports idicated that Akt/PKB is activated by cellular stress and heat shock through association with Hsp27 [48] and that the $\beta$-adrenergic agonist, isoproterenol, can activate Akt/PKB in a wortmannin-resistant manner [49]. But the significance of these findings remains to be determined.

\section{Proteins bind and regulate $\mathrm{Akt} / \mathrm{PKB}$}

Many proteins have been reported to interact with $\mathrm{Akt} / \mathrm{PKB}$, but most of them are substrates for Akt/PKB and do not affect Akt/PKB kinase activity [50]. However, several proteins have been shown to regulate Akt/PKB activity, suggesting that there may be transient regulation of this kinase (Table 1). In recent studies, several proteins that bind to and inhibit the activation of Akt/PKB by reducing its phosphorylation on Thr308 and Ser473 have been identified. For example, carboxyl-terminal modulator protein (CTMP) is a novel protein identified as a binding partner for the carboxyl-terminal of Akt/PKB by yeast two-hybrid screening. It inhibits Akt/PKB signaling by reducing phosphorylation on Ser473 and reverses Akt/PKB dependent cancer cell growth and tumour formation in nude mice [51]. Trb3 is the mammalian homologue of tribbles, a cdc25 binding protein of Drosophila, identified by two-hybrid interaction cloning as a Akt/PKB binding protein [52]. Based on its functions, it is likely that Trb3 is a negative regulator of Akt/PKB activation. This protein binds to the central region of the kinase domain of Akt/PKB. Overexpression of $\mathrm{Trb} 3$ reduces phosphorylation and inhibits Akt/PKB activation in a Trb3Akt/PKB interaction-dependent manner [52]. Keratin K10, a major component of intermediate filaments in the cytoskeletal structure, binds to Akt/PKB and sequestrates it to the cytoskeleton, and inhibits its intracellular translocation, which causes inactivation of Akt/PKB kinase activity and inhibits cell proliferation [53].On the other hand, positive regulators of Akt/PKB by several other proteins such as Hsp90, Hsp27, Tcl1, Grb10, Ft1, were identified to interact with different domains of Akt/PKB. The Hsp family of proteins is induced by heat shock and act as molecular chaperones that promote refolding and stabilization, or destabilization, of their client proteins in response to extracellular stresses. To date, two kinds of Hsp molecules have been reported to bind to Akt/PKB and regulate its activity. Hsp27 specifically binds to Akt/PKB isoforms following different stress treatments [54]. A recent report has shown that Hsp27-Akt/PKB interaction leads to activation of Akt/PKB and inhibition of apoptosis in neutrophils [55]. Hsp90 has been reported to act as a kinase chaperone for several tyrosine and serine/threonine kinases in cooperation with cdc37, and inhibitors of Hsp90 cause Akt/PKB degradation [56]. Grb10 is a member of the Grb family of proteins identified by their ability to bind to phosphorylated tyrosine residues in the 
Table 1 Akt/PKB binding proteins

\begin{tabular}{lll}
\hline \multicolumn{1}{c}{$\begin{array}{c}\text { Binding pro- } \\
\text { teins }\end{array}$} & \multicolumn{1}{c}{ Biological significance } & Refs \\
\hline Actin & $\begin{array}{l}\text { Localization of Akt/PKB to the cytoskeleton; cdc42 is also involved } \\
\text { CTMP }\end{array}$ & $\begin{array}{l}\text { Binds to the C-terminus of Akt/PKB and blocks phosphorylation and acti- } \\
\text { vation }\end{array}$ \\
Erk1/2 & $\begin{array}{l}\text { Akt/PKB binds a complex of ERK1/2, Rsk and PDK1 to regulate apoptosis [63] } \\
\text { Ft1 }\end{array}$ & $\begin{array}{l}\text { Enhance the phosphorylation of Akt/PKB by promoting its interaction with } \\
\text { the upstream kinase PDK1 }\end{array}$ \\
Grb10 & $\begin{array}{l}\text { Recruit Akt/PKB to the plasma membrane in response to c-kit activation } \\
\text { Hsp90 }\end{array}$ & $\begin{array}{l}\text { Act as a kinase chaperone for several tyrosine and serine/threonine kinase } \\
\text { in cooperation with cdc37 }\end{array}$ \\
Hsp27 & $\begin{array}{l}\text { Specifically binds Akt/PKB isoforms following different stress treatments } \\
\text { Jip1 }\end{array}$ & $\begin{array}{l}\text { PKBa/Akt1 binding blocks JNK binding to JIP1 and delays apoptosis } \\
\text { Keratin K10 }\end{array}$ \\
Inactivate of Akt/PKB kinase activity and inhibits cell proliferation & {$[64]$} \\
Periplakin & $\begin{array}{l}\text { Binds to the PH domain of Akt/PKB and mediates localization to the intra- } \\
\text { cellular network }\end{array}$ \\
Posh & $\begin{array}{l}\text { PKBß/Akt2 binding blocks MLK-MKK-JNK complex formation and apop- } \\
\text { tosis }\end{array}$ \\
Tc11 & $\begin{array}{l}\text { Positive regulator of Akt/PKB and overexpressed in several T or B cell } \\
\text { malignancy }\end{array}$ \\
Trb3 & $\begin{array}{l}\text { Blocks Akt/PKB activation in hepatocytes } \\
{[39,59,60]}\end{array}$ \\
\hline
\end{tabular}

EGF receptor [57]. Grb10 constitutively forms a complex with Akt/PKB and interacts with the ckit receptor tyrosine kinase in its ligand, in a stem cell factor (SCF)-dependent manner [58]. Tcl1 (Tcell leukaemia 1) is a $14-\mathrm{kDa}$ protein. It was identified as an Akt/PKB binding protein by yeast two-hybrid screening. The mechanism for Tcllmediated activation of Akt/PKB requires further work because two different mechanisms have been proposed $[39,59,60]$. Ft1 was identified from a cDNA library screening using a green fluorescent protein-based protein-fragment complementation assay. Ft1 protein interacts directly with Akt/PKB to enhance the phosphorylation of both regulatory sites by promoting its interaction with the upstream kinase PDK1. Further, the modulation of PKB activity by Ft1 has a strong effect on the apoptosis susceptibility of T lymphocytes treated with glucocorticoids [61].

\section{Regulation of cell survival by Akt/PKB}

The Akt/PKB signaling pathway is now recognized as one of the most critical pathways in regulating cell survival. The activation of Akt pathway provides cells with a survival signal that allows them to withstand apoptotic stimuli [67]. Akt/PKB, a PI3-kinase activated protein kinase, is a principal mediator of cell survival. In recent years, many reports elucidate the important roles of Akt/PKB signaling pathway in cell survival in several cancers [68-71]. Recently, our lab in collaboration with Wang lab at Duke demonstrated that a secreted protein called periostin that is overexpressed in tumors can activate the $\mathrm{Akt} / \mathrm{PKB}$ signaling pathway through the $\alpha_{\mathrm{v}} \beta_{3}$ integrins to augment cancer cell and endothelial cell 
survival and prevent stress-induced apoptosis, and dramatically enhance metastatic growth of colon [68]. Akt/PKB has direct effects on the apoptosis pathway, for example, targeting the pro-apoptotic Bcl-2 related protein, BAD. It also affects the transcriptional response to apoptotic stimuli, for example, by affecting on Forkhead factors and the activity of the p53 family. In addition, novel connections between the metabolic effects of Akt/PKB and its control of survival have recently been made. Targets of Akt/PKB signalling that are believed to promote cell survival are illustrated in Fig. 3.

\section{Direct regulation of cell survival}

A large amount of evidence has suggested that one of the major functions of Akt/PKB is to promote growth factor-mediated cell survival and to block apoptosis. Apoptosis in mammalian cells is a multistep process. In the current model, an early event is the loss of mitochondrial integrity fol- lowed by cytochrome c release. The released cytochrome $\mathrm{c}$ then binds to the apoptotic protease-activating factor (Apaf-1) and activates it. Apaf- 1 then binds to, cleaves and activates the cysteine protease, caspase- 9 . This initiates a caspase cascade culminating in the activation of the executioner caspases [72]. Critical regulators in this pathway are various members of the Bcl-2 family. These proteins include anti-apoptotic effectors such as Bcl-2 and Bcl-xL and their proapoptotic counterparts such as Bad, Bid, and Bik (the BH3 subfamily) and Bax and Bak (the Bax subfamily) [73].

\section{BAD}

$\mathrm{BAD}$ is a member of the $\mathrm{Bcl}-2$ family of proteins that binds to $\mathrm{Bcl}-2$ or $\mathrm{Bcl}-\mathrm{X}$ and inhibits their antiapoptotic potential. But when BAD is phosphorylated on Ser136 by Akt/PKB, it does not exhibit pro-apoptotic activity in cells, so it is thought to be one of the direct targets of Akt/PKB in promoting cell survival $[74,75]$. The potential of phosphorylated BAD to inhibit apoptosis might be regulated by its formation of complexes with other proteins.

Table 2 Some transcription factors regulated by Akt/PKB to control cell survival.

\begin{tabular}{|c|c|c|c|}
\hline Transcription factors & Phosphorylation site & Biological significance & Refs \\
\hline \multirow[t]{2}{*}{ Forkhead family } & $\begin{array}{l}\text { Thr24, Ser256, Ser319 } \\
\text { (FKHR) } \\
\text { (FKHR, FKHRL1, AFX) } \\
\text { Thr32, Ser253, Ser315 } \\
\text { (FKHRL1) }\end{array}$ & $\begin{array}{l}\text { promotes nuclear exclusion; } \\
\text { association with } 14-3-3 \text { proteins; }\end{array}$ & \\
\hline & $\begin{array}{l}\text { Thr28, Ser193, Ser258 } \\
\text { (AFX) }\end{array}$ & $\begin{array}{l}\text { prevention of transcription of proapop- } \\
\text { totic genes }\end{array}$ & {$[85]$} \\
\hline Ik-B kinase & Thr23 & $\begin{array}{l}\text { induction of NF- } \mathrm{kB} \text { transcriptional activ- } \\
\text { ity }\end{array}$ & {$[87]$} \\
\hline $\operatorname{Mdm} 2$ & Ser166, Ser186 & $\begin{array}{l}\text { induction of its nuclear import or up- } \\
\text { regulation of its ubiquitin ligase activity }\end{array}$ & {$[92,93]$} \\
\hline CREB & Ser133 & $\begin{array}{l}\text { increased transcription of CREB-regulat- } \\
\text { ed survival genes }\end{array}$ & {$[94,95]$} \\
\hline YAP & Ser127 & acts as a suppressor of apoptosis & [96] \\
\hline
\end{tabular}




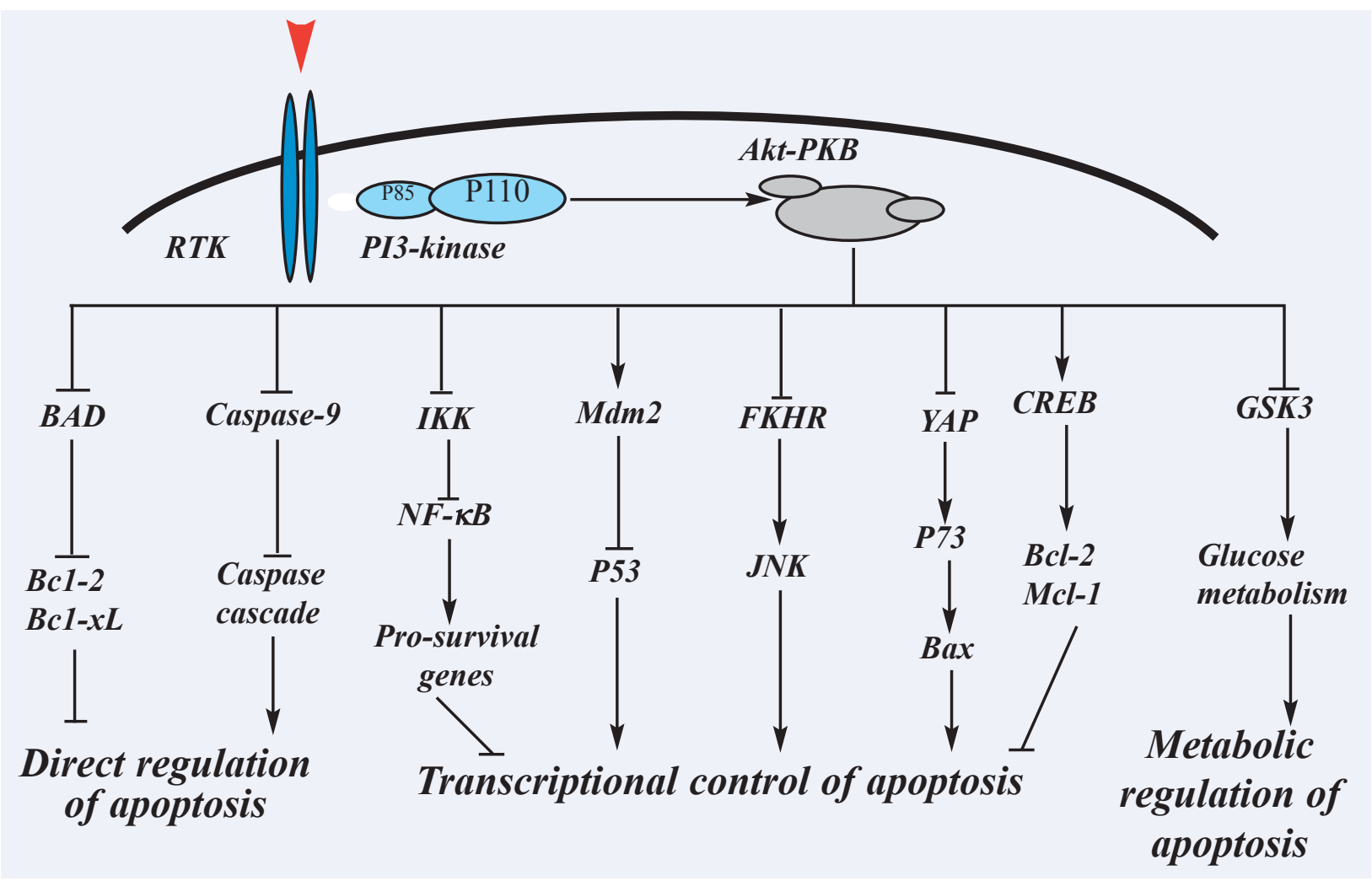

Fig. 3 Multiple mechanisms of cell survival regulation by Akt/PKB. GF: growth factor, p: phosphorylation, RTK: receptor tyrosine kinase.

Once phosphorylated, BAD is released from a complex with $\mathrm{Bcl}-2 / \mathrm{Bcl}-\mathrm{X}$ that is localized on the mitochondrial membrane, and forms a complex with 143-3 proteins in the cytosol, thus inactivates its proapoptotic function [76].

\section{Caspase-9}

Caspase- 9 acts as an initiator and an effecter of apoptosis [77]. Human caspase-9 has been reported to be phosphorylated on Ser196 by Akt/PKB, resulting in attenuation of its activity [78]. However, the site phosphorylated of caspase-9 is not conserved in other lower mammalian species such as mouse or rat, suggesting that this regulation of Akt/PKB is not likely to be a major physiological regulatory pathway or the phosphorylation of this site is specific for higher species [79].

\section{SAPK}

The stress-activated protein kinase (SAPK) pathway regulates cellular responses to stress or cytokines. The SAPK system consists of two groups of kinase, JNK and p38 MAP kinase pathways [80]. It has been reported that Akt/PKB can phosphorylate three kinases upstream of SAPK. Apoptosis signal-regulating kinase 1 (ASK1) is one of the MAP kinase kinase kinases (MKKK) that interacts with and is phosphorylated by $\mathrm{Akt} / \mathrm{PKB}$ on Ser83, which results in the inhibition of apoptosis induced by ASK1 [81]. Akt/PKB can phosphorylate another MKKK upstream of SAPK, the mixed lineage kinase 3 (MLK3). Akt/PKB interacts with and phosphorylates MLK3 on Ser674 and this causes MLK3 inactivation and the promotion of cell survival [82]. Similar to the two MKKKs mentioned above, SEK1/ MKKK4 binds to and is phosphorylated on Ser78 by Akt/PKB, resulting in SEK1 inactivation and inhibition of ultraviolet (UV)-induced apoptosis [83]. The above observations suggest that the SAPK pathway is an important target for Akt/PKB regulation to promote cell survival.

\section{Transcriptional control of cell survival}

Recent studies have shown that $\mathrm{Akt} / \mathrm{PKB}$ is able to regulate cell survival through transcriptional 
factors that are responsible for pro- as well as anti-apoptotic genes. Many of the recently identified substrates for Akt/PKB have been found to be involved in transcriptional regulation of cell survival (Table 2).

\section{FoxO Forkhead}

The Forkhead (FoxO or FH) family of transcription factors was first identified from the genetic analysis of C. elegans [84]. It has been found that all four isoforms of $\mathrm{FoxO}$ proteins (FKHR/FoxO1, FoxO2, FKHRL1/FoxO3 and AFX/FoxO4) could be phosphorylated by Akt/PKB directly. The phosphorylated FoxO proteins can regulate cell survival by operating their target genes. A number of FoxO target genes may be important in the inhibiting of cell survival. The target genes for the FoxO family are thought to be extracellular ligands, including the Fas ligand, TRAIL (TNF-related apoptosis-inducing ligand) and TRADD (TNF receptor type 1 associated death domain), and intracellular components for apoptosis like Bim (bcl-2 interacting mediator of cell death), a pro-apoptotic Bcl-2 family member, and Bcl-6 [85].

\section{NF-kB}

The transcription factor nuclear factor- $\kappa \mathrm{B}$ (NF$\kappa \mathrm{B})$ family is a key regulator of the immune response, and deregulation of its activity is implicated in the development of diseases such as autoimmune disease and cancer [86]. In most cases, the activation of NF- $\kappa \mathrm{B}$ is dependent on the phosphorylation of I $\mathrm{KB}$ kinase (IKK) complex and degradation of $\mathrm{I} \kappa \mathrm{B}$, an inhibitor of NF- $\kappa \mathrm{B}$. $\mathrm{Akt} / \mathrm{PKB}$ has been shown to regulate IKK activity in both direct and indirect manner [87]. This leads to the nuclear translocation and activation of NF- $\mathrm{BB}$, and transcription of NF- $\mathrm{KB}-$ dependent pro-survival genes, including $\mathrm{Bcl}-\mathrm{xL}$, caspase inhibitors and c-Myb $[88,89]$.

\section{Mdm2}

Murine double minute $2(\mathrm{Mdm} 2)$ is an oncogene product induced by p53 [90]. p53 is a major regulator of cell death in response to stresses, especially those involving DNA damage [91]. The level and function of the p53 protein is strongly inhibited through the action of the E3 ubiquitin ligase Mdm2. Akt/PKB has been reported to bind to and phosphorylate Mdm2 on two residues, Ser166 and Ser186, resulting in induction of its nuclear import or up-regulation of its ubiquitin ligase activity [92,93]. Thus, Akt/PKB could result in promoting the inactivation or degradation of p53 and undermine the p53-mediated proapoptotic transcriptional response.

\section{CREB}

Cyclic AMP (cAMP)-response element binding protein (CREB) transcription factor is able to be phosphorylated by Akt/PKB on Ser133. This process results in increasing transcriptional activation of CREB and affinity of CREB to its co-activator CRB [94].CREB has also been shown to mediate Akt/PKB-induced expression of some antiapoptotic genes, such as bcl-2, mcl-1 [95].

\section{YAP}

Yes-associated protein (YAP) is a recently identified Akt/PKB substrate, purified from 14-3-3 binding proteins. Akt/PKB is able to phosphorylate YAP on Ser127 in a PI3-kinase-dependent manner. Phosphorylated YAP acts as a suppressor of apoptosis mediated by the transcriptional activity of p73 [96].

\section{Metabolic regulation of cell survival}

A major physiological function of Akt/PKB is the regulation of cell metabolism. When high levels of insulin are present, glycogen synthase kinase 3 (GSK3) is inhibited upon phosphorylation by $\mathrm{Akt} / \mathrm{PKB}$ with the result that the storage of glucose as glycogen is promoted [97]. GSK3 is also involved in many other signaling pathways, including the $\beta$-catenin-TCF/LEF transcriptional pathway [98]. The inhibition of GSK3 has been found to be protective against apoptosis in many circumstances, although the molecular basis for this is not understood [99]. So an interesting hypothesis has been proposed that the effects of Akt/PKB on cell survival are connected with its effects on cell metabolism. Withdrawal of growth factors from cells leads to a reduction in their ability to utilize nutrients in the medium, resulting in a depletion of ATP and glucose-derived 
metabolites within the cell [100]. Akt/PKB activation allows cells to continue to import glucose and amino acids $[101,102]$. In particular, the ability of Akt/PKB to promote glucose utilization can prevent the induction of conformational activation of Bax and subsequent cell apoptosis following treatment with apoptotic stimuli [103]. Although there are some mechanistic details missing in the metabolic connection between $\mathrm{Akt} / \mathrm{PKB}$ and cell survival regulation, it is likely that these puzzles will be solved soon.

\section{Conclusions}

In the past decades, the mechanisms for Akt/PKB activation, the lipid second messenger-mediated phosphorylation of Akt/PKB, have been well characterized, and our knowledge of Akt/PKB in promoting cell survival and proliferation has expanded rapidly. Nevertheless, a number of major questions still remain unanswered. For example, the mechanism for the activation of Akt/PKB, particularly the regulation of the S473 site, is still not fully clear. In addition, although $\mathrm{Akt} / \mathrm{PKB}$ is strongly implicated in the regulation of cell survival and growth, the physiological substrates of $\mathrm{Akt} / \mathrm{PKB}$ that drive these processes remain to be completely identified. A number of strong candidates have emerged, such as GSK-3 and forkhead proteins, but their overall importance, compared to other potential substrates, is not yet clear. Akt/PKB has been an attractive therapeutic target. In recent years, specific Akt/PKB inhibitor has been identified, such as deguelin which proved a useful tool for cancer therapy $[104,105]$. So the progress of pharmaceutical compounds that specifically target $\mathrm{Akt} / \mathrm{PKB}$ in tumor will be of interest to those in the field.

\section{Acknowledgement}

This work was supported by the grants from National Natural Science Foundation of China (No. 30170463, 30370307, 30400239).

\section{References}

1. Nicholson K.M., Anderson N.G., The Akt/PKB signalling pathway in human malignancy, Cell signal, 14: 381-395, 2002

2. Hajduch E, Litherland G.J., Hundal H.S., Protein kinase B (Akt/PKB)-a key regulator of glucose transport?, FEBS Lett., 492: 199-203, 2001

3. Coffer P.J., Woodgett J.R., Molecular cloning and characterization of a novel putative protein-serine kinase related to the cAMP dependent and protein kinase C families, Eur. $J$. Biochem., 201: 475-481, 1991

4. Jones P.F., Jakubowicz T., Pitossi F.J., Maurer F., Hemmings B.A., Molecular cloning and identification of a serine/threonine protein kinase of the second-messenger subfamily, Proc. Natl. Acad. Sci. USA., 88: 4171-4175, 1991

5. Bellacosa A., Testa J.R., Staal S.P., Tsichlis P.N., A retroviral oncogene, akt, encoding a serine-threonine kinase containing an SH2-like region, Science, 254: 274-277, 1991

6. Jones P.F., Jakubowicz T., Hemmings B.A., Molecular cloning of a second form of rac protein kinase, Cell Regul., 2: 1001-1009, 1991

7. Cheng J.Q., Godwin A.K., Bellacosa A., Taguchi T., Franke T.F., Hamilton T.C., Tsichlis P.N., Testa J.R., AKT2, a putative oncogene encoding a member of a subfamily of protein-serine/threonine kinases, is amplified in human ovarian carcinomas, Proc. Natl. Acad. Sci. USA., 89: 9267-9271, 1992

8. Brodbeck D., Cron P., Hemmings B.A., A human protein kinase $\mathrm{B}$ with regulatory phosphorylation sites in the activation loop and in the C-terminal hydrophobic domain, $J$. Biol. Chem., 274: 9133-9136, 1999

9. Brazil D.P., Hemmings B.A., Ten years of protein kinase B signalling: a hard Akt to follow, Trends Biochem. Sci., 26: 657-664, 2001

10. Tyers M., Rachubinski R.A., Stewart M.I., Varrichio A.M., Shorr R.G., Haslam R.J., Harley C.B., Molecular cloning and expression of the major protein kinase $\mathrm{C}$ substrate of platelets, Nature, 333: 470-473, 1998

11. Lietzke S.E., Bose S., Cronin T., Klarlund J., Chawla A., Czech M.P., Lambright D.G., Structural basis of 3-phosphoinositide recognition by pleckstrin homology domains, Mol Cell, 6: 385-394, 2000

12. Ferguson K.M., Kavran J.M., Sankaran V.G., Fournier E., Isakoff S.J., Skolnik E.Y., Lemmon M.A., Structural basis for discrimination of 3-phosphoinositides by pleckstrin homology domains, Mol. Cell, 6: 373-384, 2000

13. James S.R., Downes C.P., Gigg R., , Grove S.J., Holmes A.B., Alessi D.R., Specific binding of the Akt-1 protein kinase to phosphatidylinositol 3,4,5-trisphosphate without subsequent activation, Biochem. J., 315: 709-713, 1996

14. Frech M., Andjelkovic M., Ingley E., Reddy K.K., Falck J.R., Hemmings B.A., High affinity binding of inositol phosphates and phosphoinositides to the Pleckstrin homology domain of RAC protein kinase B and their influence on kinase activity, J. Biol. Chem., 272: 8474-8481, 1997

15. Thomas C.C., Deak M., Alessi D.R., van Aalten D.M., High-resolution structure of the pleckstrin homology 
domain of Akt/PKB bound to phosphatidylinositol $(3,4,5)$ trisphosphate, Curr. Biol., 12: 1256-1262, 2002

16. Peterson R.T., Schreiber S.L., Kinase phosphorylation: keeping it all in the family, Curr. Biol., 9: R521-524, 1999

17. Alessi D.R., Andjelkovic M., Caudwell B., Cron P., Morrice N., Cohen P., Hemmings B.A., Mechanism of activation of protein kinase $\mathrm{B}$ by insulin and IGF-1, EMBO. J., 15: 6541-6551, 1996

18. Andjelkovic M., Alessi D.R., Meier R., Fernandez A., Lamb N.J., Frech M., Cron P., Cohen P., Lucocq J.M., Hemmings B.A., Role of translocation in the activation and function of protein kinase B, J. Biol. Chem., 272: 3151531524, 1997

19. Brodbeck D., Hill M.M., Hemmings B.A., Two splice variants of protein kinase $\mathrm{B} g$ have different regulatory capacity depending on the presence or absence of the regulatory phosphorylation site serine 472 in the carboxyl-terminal hydrophobic domain, J. Biol. Chem., 276: 29550-29558, 2001

20. Konishi H., Kuroda S., Tanaka M., Matsuzaki H., Ono Y., Kameyama K., Haga T., Kikkawa U., Molecular cloning and characterization of a new member of the RAC protein kinase family: association of the pleckstrin homology domain of three types of RAC protein kinase with protein kinase $\mathrm{C}$ subspecies and beta gamma subunits of $\mathrm{G}$ proteins, Biochem. Biophys. Res. Commun., 216: 526-534, 1995

21. Wymann M.P., Zvelebil M., Laffargue M., Phosphoinositide 3-kinase signaling-which way to target?, Trends Pharmacol. Sci., 24: 366-376, 2003

22. Simpson L., Parsons R., PTEN: life as a tumor suppressor, Exp. Cell. Res, 264: 29-41, 2001

23. Lemmon M.A., Ferguson K.M., Signal-dependent membrane targeting by pleckstrin homology $(\mathrm{PH})$ domains, Biochem. J., 350: 1-18, 2000

24. Andjelkovic M., Alessi D.R., Meier R., Fernandez A., Lamb N.J., Frech M., Cron P., Cohen P., Lucocq J.M., Hemmings B.A., Role of translocation in the activation and function of protein kinase B, J. Biol. Chem., 272: 31515-31524, 1997

25. Stephens L., Anderson K., Stokoe D., ErdjumentBromage H., Painter G.F., Holmes A.B., Gaffney P.R., Reese C.B., McCormick F., Tempst P., Coadwell J., Hawkins P.T., Protein kinase B kinases that mediate phosphatidylinositol 3,4,5-trisphosphate-dependent activation of protein kinase B, Science, 279: 710-714,1998

26. Toker A., Newton A.C., Akt/protein kinase B is regulated by autophosphorylation at the hypothetical PDK-2 site, J. Biol. Chem., 275: 8271-8274, 2000.

27. Persad S., Attwell S, Gray V., Mawji N., Deng J.T., Leung D., Yan J., Sanghera J., Walsh M.P., Dedhar S., Regulation of Akt/PKB-serine 473 phosphorylation by integrin-linked kinase: critical roles for kinase activity and amino acids arginine 211 and serine 343, J. Biol. Chem., 276: 27462-27469, 2001

28. Conus N.M., Hannan K.M., Cristiano B.E., Hemmings B.A., Pearson R.B., Direct identification of tyrosine 474 as a regulatory phosphorylation site for the Akt protein kinase, J. Biol. Chem., 277: 38021 38028, 2002
29. Jiang T., Qiu Y., Interaction between Src and a C-terminal proline-rich motif of Akt is required for Akt activation, $J$. Biol. Chem., 278: 15789-15793, 2003

30. Mora A., Komander D., van Aalten D.M., Alessi D.R., PDK1, the master regulator of AGC kinase signal transduction, Semin Cell Dev. Biol., 15: 161-170, 2004

31. Biondi R.M., Cheung P.C., Casamayor A., Deak M., Currie R.A., Alessi D.R., Identification of a pocket in the PDK1 kinase domain that interacts with PIF and the C-terminal residues of PKA, EMBO. J., 19: 979-988, 2000

32. Biondi R.M., Kieloch A., Currie R.A., Deak M., Alessi D.R., The PIF-binding pocket in PDK1 is essential for activation of S6K and SGK, but not PKB, EMBO. J., 20: 43804390, 2001

33. Collins B.J., Deak M., Arthur J.S., Armit L.J., Alessi D.R., In vivo role of the PIF-binding docking site of PDK1 defined by knock-in mutation, EMBO. J., 22: 4202-4211, 2003

34. Anderson K.E., Coadwell J., Stephens L.R., Hawkins P.T., Translocation of PDK-1 to the plasma membrane is important in allowing PDK-1 to activate protein kinase B, Curr. Biol., 8: 684-691, 1998

35. Balendran A., Casamayor A., Deak M., Paterson A., Gaffney P., Currie R., Downes C.P., Alessi D.R., PDK1 acquires PDK2 activity in the presence of a synthetic peptide derived from the carboxyl terminus of PRK2, Curr. Biol., 9: 393-404, 1999

36. Williams M.R., Arthur J.S., Balendran A., van der Kaay J., Poli V., Cohen P., Alessi D.R., The role of 3-phosphoinositide-dependent protein kinase 1 in activating AGC kinases defined in embryonic stem cells, Curr. Biol., 10: 439-448, 2000

37. Hill M.M., Andjelkovic M., Brazil D.P., Ferrari S., Fabbro D., Hemmings B.A., Insulin-stimulated protein kinase B phosphorylation on Ser-473 is independent of its activity and occurs through a staurosporine-insensitive kinase, J. Biol. Chem., 276: 25643-25646, 2001

38. Toker A., Newton A.C., Akt/Protein kinase B is regulated by autophosphorylation at the hypothetical PDK-2 site, $J$. Biol. Chem., 275: 8271-8274, 2000

39. Laine J., Kunstle G., Obata T., Sha M., Noguchi M., The protooncogene TCL1 is an Akt kinase coactivator, Mol. Cell, 6:395-407, 2000

40. Hill M.M., Andjelkovic M., Brazil D.P., Ferrari S., Fabbro D., Hemmings B.A., Insulin-stimulated protein kinase B phosphorylation on Ser-473 is independent of its activity and occurs through a staurosporine-insensitive kinase, J. Biol. Chem., 276: 25643-25646, 2001

41. Delcommenne M., Tan C., Gray V., Rue L., Woodgett J., Dedhar S., Phosphoinositide-3-OH kinase-dependent regulation of glycogen synthase kinase 3 and Akt/PKB by the integrin-linked kinase, Proc. Natl. Acad. Sci. USA., 95: 11211-11216, 1998

42. Lynch D.K., Ellis C.A., Edwards P.A., Hiles I.D., Integrin-linked kinase regulates phosphorylation of serine 473 of protein kinase B by an indirect mechanism, Oncogene, 18: 8024-8032, 1999

43. Persad S., Attwell S., Gray V., Mawji N., Deng J.T., Leung D., Yan J., Sanghera J., Walsh M.P., Dedhar S., Regulation of Akt/PKB-serine 473 phosphorylation by inte- 
grin-linked kinase: critical roles for kinase activity and amino acids arginine 211 and serine 343, J. Biol. Chem., 276: 27462-27469, 2001

44. Chen R., Kim O., Yang J., Sato K., Eisenmann K.M., McCarthy J., Chen H., Qiu Y., Regulation of Akt/PKB activation by tyrosine phosphorylation, J. Biol. Chem., 276: 31858-31862, 2001

45. Sable C.L., Filippa N., Hemmings B., Van Obberghen E., cAMP stimulates protein kinase B in a Wortmannininsensitive manner, FEBS. Lett., 409: 253-257, 1997

46. Filippa N., Sable C.L., Filloux C., Hemmings B.A., Van Obberghen E., Mechanism of protein kinase B activation by cyclic AMP-dependent protein kinase, Mol. Cell Biol., 19: 4989-5000, 1999

47. Perez-Garcia M.J., Cena V., de Pablo Y., Llovera M., Comella J.X., Soler R.M., Glial cell line-derived neurotrophic factor increases intracellular calcium concentration. Role of calcium/calmodulin in the activation of the phosphatidylinositol 3-kinase pathway, J. Biol. Chem., 279: 6132-6142, 2004

48. Konishi H., Matsuzaki H., Tanaka M., Takemura Y., Kuroda S., Ono Y., Kikkawa U., Activation of protein kinase B (Akt/RAC-protein kinase) by cellular stress and its association with heat shock protein Hsp27, FEBS. Lett., 410: 493-498, 1997

49. Moule S.K., Welsh G.I., Edgell N.J., Foulstone E.J., Proud C.G., Denton R.M., Regulation of protein kinase B and glycogen synthase kinase-3 by insulin and betaadrenergic agonists in rat epididymal fat cells. Activation of protein kinase B by wortmannin-sensitive and -insensitive mechanisms, J. Biol. Chem., 272: 7713-7719, 1997

50. Brazil D.P., Park J., Hemmings B.A., PKB binding proteins: Getting in on the Akt, Cell, 111: 293-303, 2002

51. Maira S.M., Galetic I., Brazil D.P., Kaech S., Ingley E., Thelen M., Hemmings B.A., Carboxyl-terminal modulator protein (CTMP), a negative regulator of Akt/PKB and v-Akt at the plasma membrane, Science, 294: 374-380, 2001

52. Du K., Herzig S., Kulkarni R.N., Montminy M., TRB3: a tribbles homolog that inhibits Akt/PKB activation by insulin in liver, Science, 300: 1574-1577, 2003

53. Paramio J.M., Segrelles C., Ruiz S., Jorcano J.L., Inhibition of protein kinase $\mathrm{B}(\mathrm{PKB})$ and $\mathrm{PKC}$-mediates keratin K10-induced cell cycle arrest, Mol. Cell Biol., 21: 74497459,2001

54. Konishi H., Matsuzaki H., Tanaka M., Activation of protein kinase B (Akt/RAC-protein kinase) by cellular stress and its association with heat shock protein Hsp27, FEBS Lett., 410: 493-498, 1997

55. Rane M.J., Pan Y., Singh S., Powell D.W., Wu R., Cummins T., Chen Q., McLeish K.R., Klein J.B., Heat shock protein 27 controls apoptosis by regulating Akt activation, J. Biol. Chem., 278: 27828-27835, 2003

56. Solit D.B., Basso A.D., Olshen A.B., Scher H.I., Rosen N., Inhibition of heat shock protein 90 function down-regulates Akt kinase and sensitizes tumors to Taxol, Cancer Res., 63: 2139-2144, 2003

57. Han D.C., Shen T.L., Guan J.L., The Grb7 family proteins: structure, interactions with other signaling molecules and potential cellular functions, Oncogene, 20: 6315-6321, 2001
58. Jahn T., Seipel P., Urschel S., Peschel C., Duyster J., Role for the adaptor protein Grb10 in the activation of Akt, Mol. Cell Biol., 22: 979-991, 2002

59. Pekarsky Y., Koval A., Hallas C., Bichi R., Tresini M., Malstrom S., Russo G., Tsichlis P., Croce C.M., Tcl1 enhances Akt kinase activity and mediates its nuclear translocation, Proc. Natl. Acad. Sci. USA., 97: 3028-3303, 2000

60. Auguin D., Barthe P., Royer C., Stern M.H., Noguchi M., Arold S.T., Roumestand C., Structural basis for the coactivation of protein kinase B by T-cell leukemia-1 (TCL1) family proto-oncoproteins, J. Biol. Chem., 279: 3589035902, 2004

61. Remy I., Michnick S.W., Regulation of apoptosis by the Ft1 protein, a new modulator of Akt/PKB, Mol. Cell Biol., 24: 1493-1504, 2004

62. Cenni V., Sirri A., Riccio M., Lattanzi G., Santi S., de Pol A., Maraldi N.M., Marmiroli S., Targeting of the Akt/PKB kinase to the actin skeleton, Cell Mol. Life Sci., 60: 2710-27120, 2003

63. Sinha D., Bannergee S., Schwartz J.H., Lieberthal W., Levine J.S., Inhibition of ligand-independent ERK1/2 activity in kidney proximal tubular cells deprived of soluble survival factors upregulates Akt and prevents apoptosis, $J$. Biol. Chem., 279: 10962-10972, 2003

64. Kim A.H., Yano H., Cho H., Meyer D., Monks B., Margolis B., Birnbaum M.J., Chao M.V., Akt1 regulates a JNK scaffold during excitotoxic apoptosis, Neuron, 35: 697-709, 2002

65. van den Heuvel A.P., de Vries-Smits A.M., van Weeren P.C., Dijkers P.F., de Bruyn K.M., Riedl J.A., Burgering B.M., Binding of protein kinase B to the plakin family member periplakin, J. Cell Sci., 115: 3957-3966, 2002

66. Figueroa C., Tarras S., Taylor J., Vojtek A.B., Akt2 negatively regulates assembly of the POSH-MLK-JNK signaling complex, J. Biol. Chem., 278: 47922-47927, 2003

67. Yao R., Cooper G.M., Requirement for phosphatidylinositol-3 kinase in the prevention of apoptosis by nerve growth factor, Science, 267: 2003-2006, 1995

68. Bao S.D., Ouyang G.L., Bai X.F., Huang Z., Ma C., Liu M., Shao R., Anderson R.M., Rich J.N., Wang X.F., Periostin potently promotes metastatic growth of colon cancer by augmenting cell survival via the Akt/PKB pathway, Cancer Cell, 5: 329-339, 2004

69. Shi Q, Bao SD, Maxwell JA, Reese1 E.D., Friedman1 H.F., Bigner D.D., Wang X. F., Rich1 J.N.. Secreted Protein Acidic, Rich in Cysteine (SPARC) Mediates Cellular Survival of Gliomas through AKT Activation, $J$. Biol. Chem., 279: 52200-52209, 2004

70. Gupta D., Syed N.A., Roesler W.J., Khandelwal R.L., Effect of overexpression and nuclear translocation of constitutively active PKB-alpha on cellular survival and proliferation in HepG2 cells, J. Cell Biochem., 93: 513, 2004

71. Wendel H.G., De Stanchina E., Fridman J.S., Malina A., Ray S., Kogan S., Cordon-Cardo C., Pelletier J., Lowe S.W., Survival signalling by Akt and eIF4E in oncogenesis and cancer therapy, Nature, 428: 332-337, 2004

72. Thornberry N.A., Lazebnik Y., Caspases: Enemies within, Science, 281: 312-316, 1998 
73. Adams J.M., Cory S., The Bcl-2 protein family: Arbiters of cell survival, Science, 281: 1322-1326, 1998

74. Del Peso L., Gonzalez-Garcia M., Page C., Herrera R., Nunez G. Interleukin-3-induced phosphorylation of BAD through the protein kinase Akt, Science, 278: 687-689, 1997

75. Datta S.R., Dudek H., Tao X., Masters S., Fu H., Gotoh Y., Greenberg M.E., Akt phosphorylation of BAD couples survival signals to the cell-intrinsic death machinery, Cell, 91: 231-241, 1997

76. Datta S.R., Brunet A., Greenberg M.E., Cellular survival: a play in three Akts, Genes Dev., 13: 2905-2927, 1999

77. Donepudi M., Grutter M.G., Structure and zymogen activation of caspases, Biophys. Chem., 145-153, 2002

78. Cardone M.H., Roy N., Stennicke H.R., Salvesen G.S., Franke T.F., Stanbridge E., Frisch S., Reed J.C., Regulation of cell death protease caspase-9 by phosphorylation, Science, 282: 1318-1321, 1998

79. Fujita E., Jinbo A., Matuzaki H., Konishi H., Kikkawa U., Momoi T., Akt phosphorylation site found in human caspase-9 is absent in mouse caspase-9, Biochem. Biophys. Res. Commun., 264: 550-555, 1999

80. Johnson G.L., Lapadat R., Mitogen-activated protein kinase pathways mediated by ERK, JNK, and p38 protein kinases, Science, 298: 1911-1912, 2002

81. Kim A.H., Khursigara G., Sun X., Franke T.F., Chao M.V., Akt phosphorylates and negatively regulates apoptosis signal-regulating kinase 1, Mol. Cell Biol., 21: 893-901, 2001

82. Barthwal M.K., Sathyanarayana P., Kundu C.N., Rana B., Pradeep A., Sharma C., Woodgett J.R., Rana A., Negative regulation of mixed lineage kinase 3 by Akt/PKB leads to cell survival, J. Biol. Chem., 278: 3897-3902, 2003

83. Park H.S., Kim M.S., Huh S.H., Park J., Chung J., Kang S.S., Choi E.J., Akt (protein kinase B) negatively regulates SEK1 by means of protein phosphorylation, J. Biol. Chem., 277: 2573-2578, 2002

84. Paradis S., Ruvkun G., Caenorhabditis elegans Akt/PKB transduces insulin receptor-like signals from AGE-1 PI3 kinase to the DAF-16 transcription factor, Genes Dev., 12: 2488-2498, 1998

85. Burgering B.M., Medema R.H., Decisions on life and death: FOXO Forkhead transcription factors are in command when Akt/PKB is off duty, J. Leukoc. Biol., 73: 689-701, 2003

86. Li Q., Verma I.M., NF- $\kappa B$ regulation in the immune system, Nat. Rev. Immunol., 2: 725-734, 2000

87. Kane L.P., Shapiro V.S., Stokoe D., Weiss A., Induction of NF-kappaB by the Akt/PKB kinase, Curr. Biol., 9: 601-604, 1999

88. Barkett M., Gilmore T.D., Control of apoptosis by Rel/NFKB transcription factors, Oncogene, 18: 6910-6924, 1999

89. Lauder A., Castellanos A., Weston K., c-Myb transcription is activated by protein kinase $\mathrm{B}(\mathrm{PKB})$ following interleukin 2 stimulation of $\mathrm{T}$ cells and is required for PKB-mediated protection from apoptosis, Mol. Cell Biol., 21: 5797-5805, 2001

90. Shimizu H., Hupp T.R., Intrasteric regulation of MDM2, Trends Biochem. Sci., 28: 346-349, 2003
91. Oren M., Decision making by p53: life, death and cancer, Cell Death Differ., 10: 431-442, 2003

92. Mayo L.D., Donner D.B., A phosphatidylinositol 3kinase/Akt pathway promotes translocation of Mdm2 from the cytoplasm to the nucleus, Proc. Natl. Acad. Sci. USA., 98: 11598-11603, 2001

93. Gottlieb T.M., Leal J.F., Seger R., Taya Y., Oren M., Cross-talk between Akt, p53 and Mdm2: possible implications for the regulation of apoptosis, Oncogene, 21: 12991303,2002

94. Du K., Montminy M., CREB is a regulatory target for the protein kinase Akt/PKB, J. Biol. Chem., 273: 32377-32379, 1998

95. Wang J.M., Chao J.R., Chen. W., Kuo M.L., Yen J.J., Yang-Yen H.F., The antiapoptotic gene mcl-1 is up-regulated by the phosphatidylinositol 3-kinase/Akt signaling pathway through a transcription factor complex containing CREB, Mol. Cell Biol., 19: 6195-7206, 1999

96. Basu S., Totty N.F., Irwin M.S., Sudol M., Downward J., Akt phosphorylates the Yes-associated protein, YAP, to induce interaction with 14-3-3 and attenuation of p73-mediated apoptosis, Mol. Cell, 11: 11-23, 2003

97. Cross D.A., Alessi D.R., Cohen P., Andjelkovich M., Hemmings B.A., Inhibition of glycogen synthase kinase-3 by insulin mediated by protein kinase B, Nature, $\mathbf{3 7 8}$ : 785789, 1995

98. Doble B.W., Woodgett J.R., GSK-3: tricks of the trade for a multi-tasking kinase, J. Cell Sci., 116: 1175-1186, 2003

99. Pap M., Cooper G.M., Role of glycogen synthase kinase-3 in the phosphatidylinositol 3-kinase/Akt cell survival pathway, J. Biol. Chem., 273: 19929-19932, 1998

100. Rathmell J.C., Vander Heiden M.G., Harris M.H., Frauwirth K.A., Thompson C.B., In the absence of extrinsic signals, nutrient utilization by lymphocytes is insufficient to maintain either cell size or viability, Mol. Cell, 6: 683-692, 2000

101. Edinger A.L., Thompson C.B., Akt maintains cell size and survival by increasing mTOR-dependent nutrient uptake, Mol. Biol. Cell, 13: 2276-2288, 2002

102. Vander Heiden M.G., Plas D.R., Rathmell J.C., Fox C.J., Harris M.H., Thompson C.B., Growth factors can influence cell growth and survival through effects on glucose metabolism, Mol. Cell Biol., 21: 5899-5912, 2001

103. Rathmell J.C., Fox C.J., Plas D.R., Hammerman P.S., Cinalli R.M., Thompson C.B., Akt-directed glucose metabolism can prevent Bax conformation change and promote growth factor-independent survival, Mol. Cell Biol., 23: 7315-7328, 2003

104. Chun K.H., Kosmeder J.W. 2nd, Sun S., Pezzuto J.M., Lotan R., Hong W.K., Lee H.Y., Effects of deguelin on the phosphatidylinositol 3-kinase/Akt pathway and apoptosis in premalignant human bronchial epithelial cells, J. Natl. Cancer Inst., 95: 291-302, 2003

105. Lee H.Y., Molecular mechanisms of deguelin-induced apoptosis in transformed human bronchial epithelial cells, Biochem. Pharmacol., 68: 1119-1124, 2004 